SYLWIA PIETROWIAK (D) https://orcid.org/0000-0001-5685-525X

University of Gdańsk

\title{
Bride kidnapping in Northern Kyrgyzstan as the initial stage of subjectivity-forming process
}

$\mathrm{O}_{1}$ the $5^{\text {th }}$ of August 2008, in the village of Kajnar ${ }^{1,2}$ in northern Kyrgyzstan, was present at the marriage ceremony of B. (30) and M. (20) - a young woman who was kidnapped to be married. She had never seen her husband before, and he had only seen her photograph. The bride had been selected by his family and friends.

In this article, I present an anthropological interpretation of bride kidnapping in Kyrgyzstan using the concept of 'person-making'. I show that marriage through bride kidnapping is a stage in the social process of building female subjectivity and reproducing families in Kyrgyzstan. In this way, I go beyond the interpretative approaches that are most frequently applied to this phenomenon and that focus on the kidnapped bride and situate the description of bride kidnapping in the context of violence, tradition, ethnic identity and male domination in the Kyrgyz society.

In the following text, I describe the actions of individual social actors both during the kidnapping and after the marriage ceremony, during the ensuing family life. The resulting image is interpreted based on categories of predation and familiarization of the Other, i.e., elements of anthropological concepts derived from the analysis of phenomena related to Amazonian indigenous peoples (see

\footnotetext{
${ }^{1}$ Kyrg. Кайнар.

${ }^{2}$ All terms in Kyrgyz language are marked in cursive, in line with the ISO 9:1995 international standard of transliteration from Cyrillic to Latin script (https://en.wikipedia.org/wiki/ ISO_9). Original Kyrgyz spelling is provided in footnotes. The same transliteration method is used in bibliography for source texts in Russian.
} 
Fausto 2000: 933-956). Although this method seems to work by analogy only, it allows me to broaden my interpretative possibilities, while I study the phenomenon in question.

In this alternative way, I demonstrate that marriage through bride kidnapping constitutes the first stage of an emerging social subjectivity of a woman, a process that involves a circle of relatives from both families.

\section{The field - Kara-buura ${ }^{3}$ region in the Kyrgyz north-west}

Kirgizstan (the Kyrgyz Republic) is a country in Central Asia, a former Soviet republic, which became independent and emerged as a nation state following the breakdown of the USSR in 1991. The country, which is still partly within the Russian sphere of influence, is the second poorest and the most unstable state in the region (Kochanek 2017: 120-124).

Marriage by bride kidnapping in Kyrgyzstan in called kyz ala kačuи (кыз ала качyy) which can be translated as "capture the girl and escape". The word ala denotes lack of consent, conflict, lack of integrity, illegitimacy, but also a trick played on someone. Kačuu is a term used for avoidance (of a blow) or escape, while $k y z$ - means a girl, young woman, daughter. ${ }^{4}$ Ala kačuu is one of the forms of marriage and does not always involve lack of consent on the part of the bride.

Sometimes, the couple agree to proceed with a 'mock kidnapping'. However, the pattern of action remains similar. On the other hand, the marriage that takes place as a result of an agreement between young people and their families involves numerous lengthy rituals, such as exchanging gifts or visits, and ends with the ceremonial bringing of the bride to her future husband's house (Pietrowiak 2014: 295).

I started my field research on modern marriages in Kyrgyzstan in 2006 and continued it in 2008, 2009 and 2014. It spanned about 4 months in total. I was staying with a Kyrgyz family in the Amanbaevo village, in the so-called "big house" inhabited by the oldest female member of the family, along with her son, her son's wife and children within a sizeable village of six thousand inhabitants. ${ }^{5}$ The destination of all my fieldtrips were the Kara-buura areas in the Talas region in north-west Kyrgyzstan, near the border with Kazakhstan. I spent most time with women: with my hostess (a senior in the family) and her four daughters-inlaw. One of them lived with her mother-in-law, the others in their own separate houses, where I sometimes spent a few days, sometimes also accompanying them on visits to their relatives in neighboring villages. Apart from participant observation of daily life in my field site, I also conducted interviews and informal conversations with the family of my hosts and with their wide circle of friends and neighbors in various parts of the village. The key event during my fieldwork

\footnotetext{
${ }^{3}$ Kyrg. Кара-Буyра.

${ }^{4}$ This word may also be used to describe a relationship.

${ }^{5}$ Data from July 2008 obtained from the Kara-buura district office.
} 
was a wedding preceded by bride kidnapping, which I witnessed in a village of Kajnar. Although it was a very difficult moment for me personally, it was also a turning point for my research. I spent three days observing the wedding-related activities, starting from the moment when the bride was brought to the house until the departure of the participants of the event. Everything that happened during the wedding became a springboard for my reflection on everyday life practices, transforming my understanding of my previous observations and the meaning of poignant stories of kidnappings I was told. For this reason, this particular wedding, although it is, of course, not the only source of my data, became the starting point for my analysis of the stories of Kyrgyz women.

The official languages in Kyrgyzstan are Kyrgyz and Russian. In the field, I used Russian, which is widely spoken in large cities and in the north. However, I have learned the basic expressions related to kinship and affinity in the Kyrgyz language, which I use in this text. Some of the customs associated with bride kidnapping for marriage are specific to this region. The empirical material presented in the text is entirely derived from research described above.

\section{Relevant literature}

Bride kidnapping as one of the forms of marriage is practiced in Kyrgyzstan and neighboring republics, but the number of such cases in Kyrgyzstan is the highest (Werner 2009: 315, 328; Sörnmo 2013: 29). Bride kidnapping in Kyrgyzstan became the focus of research for Russell L. Kleinbach, Professor of Sociology at the University of Philadelphia, who has authored most studies on the subject, based on his research there since 1999, the results of which have been systematically published. According to his data, about half of Kyrgyz marriages proceed by bride kidnapping, two thirds of them without the bride's consent (Kleinbach, Salimjanova 2007; Antoniskis 2013).

In 2017, the OBWE ${ }^{6}$ estimated that every year, twelve thousand young women are kidnapped and forced into marriage, $20 \%$ of them are raped, and that such brides are more likely to become victims of domestic violence and have restricted opportunities to pursue education and employment. The report also stated that the practice resulted in more frequent cases of early marriage among the children born to such couples, polygamy and bride kidnapping in subsequent generations. In 2013, the Kyrgyz government increased the penalty for bride kidnapping to maximum 10 years in prison, but according to NGOs, the number of cases being reported has not increased, and only rare cases where offenders were prosecuted (HRW 2018: 19).

Bride kidnapping is always a sensitive matter, it constitutes a violation of the kidnapped person, and therefore, most researchers who describe this

\footnotetext{
${ }^{6}$ Organization for Security and Co-operation in Europe, OSCE - an international organization deemed regional in line with Chapter 8 of the UN Charter.
} 
phenomenon focus precisely on the aspect of women's incapacitation (Amsler, Kleinbach 1999; Handrahan 2000, 2004; Kleinbach et al. 2005; Kleinbach, Babaiarova 2013). There are drastic descriptions of kidnapping or rapes of women forced to marry a complete stranger, based on research that has been carried out through questionnaires and interviews both in villages and big cities. Scholars presented statistics showing an increasing number of such cases (Amsler, Kleinbach 1999; Kleinbach 2003; Kleinbach et al. 2005). Russell L. Kleinbach and Lilly Salimjanova wrote a special article on the Kyrgyz customary adat law set in the context of bride kidnapping and its tradition in the past, arguing that the current form of bride kidnapping is neither in accordance with customary law, nor is supported by tradition (Kleinbach, Salimjanova 2007; Werner 2009: 315). Kleinbach also implemented an educational program targeting mainly Kyrgyz rural communities (in 2008/2009 implemented in seven provinces, and in 2008/2009 in the town of Karakul) to raise awareness of the negative consequences of bride kidnapping (Kleinbach, Babaiarova 2013). Some authors suggested that the practice constitutes a way to manifest cultural, ethnic and national identity (Handrahan 2004; Werner 2009). Joanna Mroczkowska (2010), in addition to the previously discussed aspects of this phenomenon, also highlighted the collective character of such kidnapping. In October 2016, an interdisciplinary Central Eurasia Studies Society conference focused on research related to the custom of bride kidnapping in post-Soviet Eurasia. An edited volume reflecting that discussion and suggestions for areas that require further research is the most recent scientific English-language publication related to bride kidnapping in Kyrgyzstan (Werner et al. 2018).

Bride kidnapping in Kyrgyzstan was also mentioned by Abramzon in Kyrgyzy $i$ ich ètnogenetičeskie $i$ istoriko-kul'turnye swâzi, with a note that such cases were rare and caused a series of disagreements involving whole groups of relatives on both sides and leading to serious consequences (Abramzon 1971: 230). ${ }^{7}$ Fiel'strup provides similar descriptions in his book Iz obrâdovoj žizni kirgizov načala XX veka (From the ritual life of the Kyrgyz at the beginning of the 20th century) and points out that apart from paying the full kalym, the abduction of the future bride

\footnotetext{
${ }^{7}$ An ethnographer Jan Witort who described his contemporary (end of the $19^{\text {th }}$ c.) Kyrgyz customs noted that capturing someone's daughter resulted in fighting between the families, endless raids, looting and court proceedings (Witort 1994: 157).

In Kôk-Saj village in a north-western region, I was shown a spot in the mountains with a sharp-edged rock bearing an inscription in Kyrgyz painted in red letters. „Олжобайды керген таш" - Olžobajdy kergen taš. Olžobaj - is a name, and the inscription can be translated as „The stone where Olžobaj was stretched”. The visitors attach pieces of cloth to the small gnarly trees that grow by the rock. There is a legend associated with the rock, about a žigit who fell in love with a warrior's daughter. He asked for her hand in marriage, and when he was refused, he abducted his bride. In revenge, the warriors led by the girl's father attacked and killed him and then run a flock of sheep over his body, stretched his skin over the rock which until today stands on the spot to commemorate the event. Aigine Cultural Research Center, in its publication Mazar Worship in Kyrgyzstan: Rituals and Practitioners in Talas describes this place as a mazar (a holy place of worship) and quotes a slightly different version of the story (Aitpaeva 2007: 54-55).
} 
also resulted in a fine imposed on the abductors - 9 "heads" of cattle (Fiel'strup 2002: 16-17).

Current practices differ from the ones described by Abramzon or Fiel'strup, and families that are involved usually avoid conflict, favoring an alliance. Marriages tend to create strong ties and gift exchanges between people related to each other as $k u d a^{8}$ (Kuchumkulova 2007: 122; Light 2015: 59; Ismailbekova 2017: 82-83) - i.e. through marriages between their children or relatives (Ûdahin 1965a: 437). Ismailbekova pointed out that „Of all kinship relations, this one is considered the most respected and due the most support" (Ismailbekova 2017: 83).

Borbieva offered very interesting insights, describing bride kidnapping as a ritual practice that minimized tensions caused by different understanding of love and marriage by different generations, and a powerful force for social change. She sees bride kidnapping as enabling people to start and/or maintain effective social relations and satisfy both conservative and modern interests (Borbieva 2012: 154). For couples, kidnapping is an attractive option which, like elopement, allows young people to get married even if their elders do not approve of their choice of partner or to avoid an unwanted arranged marriage that is being imposed on them (Borbieva 2012: 159).

The custom of bride kidnapping has been brought to public attention by Petr Lom's documentary film, Bride Kidnapping in Kyrgystan, which presents several stories of young women who have been abducted and forced into marriage (Lom 2004). Although the filmmakers were criticized for violating ethical standards, their ethnographic documentary is a valuable source of information.

\section{Marriage through bride kidnapping: how and who}

During the marriage ceremony following bride kidnapping, relatives play a strategic role, especially the women affines from both families. Their actions are crucial, and they translate into the concept of social reproduction that I wish to present. Some other, unrelated people also play a role: groom's male friends ${ }^{9}$ and people from his neighborhood. The Kyrgyz themselves also highlight the important role of the couple's parents, who must give their consent for the marriage. Even though everything is done with their consent, their actions during the wedding are not emphasized in any way.

Before I describe the marriage ceremony, I wish to outline the events that precede the decision to kidnap the bride. If it is not 'mock' kidnapping (when both future spouses agree to this form of marriage), the matchmaking is done

\footnotetext{
${ }^{8}$ Куда (Kyrg.).

${ }^{9}$ It is noteworthy that groom's friends are not just common acquaintances. In Kirgizstan, important ties are forged through common experiences (e.g. between classmates, fellow students, colleagues at work) - i.e. quasi-tribal relationships (Wierzbicki, Załęski 2008: 17). Such long-term relationships are maintained even after e.g. graduation and are not limited to social gatherings, even though such gatherings tend to happen on a regular basis.
} 
by members of the families concerned, particularly women (èžè è ěze $e^{10}, e ̀ n e^{11}, \check{z} e n e^{12}$, apče, ènè $\left.{ }^{13}\right)$, brothers' wives (žengeler ${ }^{14}$ ) or other women from closer or more distant family who joined the family through marriage. Aksana Ismailbekova also wrote about the great role of women in arranging marriages (deciding who to marry) in Kyrgyz patrilineal societies. Detailed knowledge of the genealogy that women often have is important (Ismailbekova 2014: 378). "Kyrgyz practice rules of exogamy, which specify the ranges and categories of relatives who are forbidden to marry members of their own lineage (uruu) within the village or anyone who shares a common patrilineal ancestor within seven generations" (Ismailbekova 2017: 82).

Quite often, the bride has never seen her future husband. The bridegroom may also get to know his "bride" only on the marriage day. However, there are situations when the bride and groom know each other or have seen the other person, and the decision to kidnap the bride is guided by mutual affection or solely made on the man's initiative. Although each of these scenarios is possible, among the women I know, the most common situation involved them being kidnapped by rejected or shunned suitors. When choosing a wife, the woman's character, reputation and the status and wealth of her family are all taken into account, while beauty is considered to be of secondary importance (interview conducted by the author 2008). This, of course, concerns cases where matchmaking is done not by the persons directly affected, but by their relatives. It is also important for the bride to be approved by the groom's parents, and especially by his mother.

\section{Men/Friends - kidnapping}

A. (39 years old): On 29 December that year, I was coming back from work. I walked past the car in which A [current husband] was sitting, as it later turned out. If only I had known that he was in that car, I would not have passed by. They dragged me into the car and drove me to my husband's house (Talas region: S.P. 2008).

Kidnapping scenarios are similar - although descriptions may vary, their main structure remains the same (Borbieva 2012: 146; Pietrowiak 2014: 296). The young woman is usually captured by men: friends, distant family members or the groom's

\footnotetext{
10 Эжэ, эже (Kyrg.) - among other meanings, the mother's younger sister (but also a stepmother, older sister, the father's brother's daughter if older than ego, step-sister older than ego, it is also a form of address for a girl or a woman that is at most 5 years older than ego; Israilova-Har'ehuzen, A`gafova 1999: 11), also тай эже.

11 Эне (Kyrg.) - the father's older brother's wife (Israilova-Har'ehuzen, A`gafova 1999: 10).

${ }^{12}$ Жеңе (Kyrg.) - among others, father's older or younger brother's wife.

${ }^{13}$ Апче, энэ (Kyrg.) - mainly an older sister (Israilova-Har' ehuzen, A`gafova 1999: 9), апче father's sister (interview led by the author).

${ }^{14}$ Žeñeler - plural. More about žeñeler in section 1.5 of this article.
} 
neighbors. ${ }^{15}$ They are young or middle-aged men, and their friendly relationship with the groom obliges them to participate and help in the bride kidnapping and during the marriage celebrations. The groom himself is present during the kidnapping but does not actively participate in it - he is just there, in the car. The abductors or other people involved in bride kidnapping (family members or the groom's friends) first observe the woman. The aim of this observation is not only to learn about her daily habits, but also about her plans, so as to kidnap her at the right moment, when she is away from her family. Often, in order to kidnap the young woman, people trick her with assistance from her own women affines (women married into her family and sometimes, from her friends who are somehow connected with the groom's family. The victim is dragged into the car, and nobody heeds her screams and crying, even though there may be witnesses. No one, except her family, can help her. Nobody cares about a woman's crying, because, in public opinion, the kidnapped woman should cry, even during the 'mock' kidnapping (Borbieva 2012: 146; Pietrowiak 2014: 297; Ismailbekova 2017: 82).

\section{Women/Affines - persuasion}

The kidnapped bride is transferred to the groom's house and entrusted to the women from his family, who - behind a special curtain - dress her in a wedding dress, put a scarf on her head (a married woman's attribute) and try to persuade her to stay in the house to which she was brought. The young woman usually resists, takes off her head scarf and cries. The women who are with her often comfort her by stroking her hair, speaking softly, and tell her about their own kidnapping, how they did not want to stay, and now have children and are happy. However, they are firm and there are many of them, so they have not only physical but also psychological advantage over the future bride.

One of the means of persuasion is the presence of an elderly woman (Abdulaeva et al. 2004), who elicits humble attitude from the young person. In Kyrgyz communities, elderly people are particularly respected, their opinion is important and should not be contradicted. If the kidnapped bride wants to leave despite the persuasion, the old woman holding bread will stand or lie down on the threshold of the house. In the article "Mothers-in-Low on the Doorstep" based on Natan Light's research, Birgit Fenzel claims that this is done by the future mother-in-law (Fenzel 2009: 92-94). By stepping over the threshold and the elderly person, the young woman would violate the norms of respect for the elderly and the groom's family would curse her (Lom 2004; Fenzel 2009: 94; Pritchard 2009), wishing her never to experience happiness in her personal life. Such a curse

\footnotetext{
${ }^{15}$ Also, mothers can initiate the practice of kidnapping brides if their sons do not get married in time. Ismailbekova described the case of a mother who used a trick to bring fiancée home for her son. "This case study shows a strong woman taking a leading role in the decision-making process and being responsible for providing her son with a wife" (Ismailbekova 2014: 380-381).
} 
can be quite effective, as the young woman who has left the abductors' house will have acquired bad opinion. If she spent the night in the groom's house, her reputation becomes dubious, because of the possibility that the young couple had sexual intercourse. ${ }^{16}$ If she continues to live in the village, where everyone knows everyone, she will not be a good candidate for a wife (Amsler, Kleinbach 1999: 9; Kleinbach et al. 2004: 197; Fenzel 2009: 94; Portisch 2009; Mroczkowska 2018). One of the women in the village of Amanbaevo had been kidnapped in this way and things progressed quickly, a goat was killed, blessings bestowed and some ženneler arrived and according to the custom, stayed all night. However, during the wedding night, the couple did not have sex. In the morning, the young woman left the groom's house and returned to her family home. The groom's family suffered material and moral losses. The bride brought shame on her family. At the time of the interview (2008) she still lived with her mother as a 37-year-old unmarried woman. Her would-be husband married another woman, who had also also been kidnapped. They have four children.

The situation is always ambiguous, and it is never certain whether the kidnapped woman will stay. I have heard of the case where a family that had acquired all their daughters-in-law through bride kidnapping did not allow a young woman from their family to stay in the abductors' house. The woman was finally abducted by another family and stayed there, so she did not suffer any negative consequences. However, I do not know what motivated the family in question and have no detailed knowledge of the incident. The second kidnapping, as my interlocutor suggested, could have been done by agreement between the two families. Also, in Kajnar, one of the groom's relatives was abducted one year before, but the family refused the marriage and took the bride home because, I was told, the incident occurred shortly after her grandmother died. One of her žene commented on that situation: S. (35 years old): She did wrong, the boy was tall, just like she is, she won't find another one like him (Talas region: 2008).

When a family decides to kidnap and bring a woman home, they must persevere. In Lom's documentary, one of the women tell the captured bride: We cannot let you go home (Lom 2004). They also run a risk. In fact, they often do not know the young woman, they do not know how she will behave, and if she won't stay, she will also bring shame on their family. "We are ashamed that she is gone" (Lom 2004), says one of the family members of the would-be bridegroom.

In Lom's documentary, two out of the several girls who were captured did not stay at the groom's house. Both later said they were very happy they did not. One of them was picked up by her parents who took her home, but she stated that if they had asked or ordered her to stay, she would have complied (Lom 2004).

The choice of the bride is very important and is not always connected with the fact that the groom likes the girl on not - both families have to face

\footnotetext{
${ }^{16}$ Most of the research done on bride kidnapping consider sex during the wedding night to be rape (Amsler, Kleinbach 1999; Handrahan 2004: 255; Mroczkowska 2010, 2018). The latter author adds that the topic is rarely and unwillingly discussed, since it "seems not to fit in with the way people talk about bride capture" (Mroczkowska 2010: 280).
} 
the consequences of their decisions. The time when the kidnapped woman is waiting for her parents to arrive is the most uncertain for both sides, and the decision they take becomes a turning point in the captured woman's life.

\section{Parents - decision}

When brought to the groom's house, the kidnapped woman is expected to write a letter to her parents, usually only providing information about her whereabouts, as she should not write anything about the kidnapping. The note is handed over to the groom's family members to be delivered in person to the addressees. The parents of the kidnapped bride are brought to the groom's house by the messengers to see for themselves what is happening there. It is up to them to decide whether the young woman should stay in the abductors' home, and the parental decision is the main - if not the only - ground for the woman's decision. Taking her back home may incur the family's potentially bad opinion, and is usually viewed negatively by their friends, relatives and neighbors.

While waiting for the bride's parents, and actually rushing to complete the task before their arrival, the groom's family slaughters a young goat, whose meat and entrails will be divided and used in different ways. The first and very important action involves an elderly woman blessing (ôpkô karuu $)^{17}$ the young couple with still "hot" respiratory organs of the slaughtered animal. The woman cannot be the groom's relative, she may, e.g. be a neighbor. The bride and groom are to sit on their heels, back to back, while the old woman touches their heads, necks and backs ${ }^{18}$ with blood stained lungs, saying (sometimes the activity itself is enough): May your love be as hot as the lungs of this goat, may you enjoy good health, have many children. An old woman in Kajnar said: May you be happy. May you have cattle in front of you and children behind you. In Kajnar, the virgin supported by three men was forced to crouch down. After the blessing, the groom said I accept. One of the men said: say I "accept", but she didn't say it. The old woman touched the groom's hand with the lungs. Then, M. - still crying - was led into the room where she was staying at all times during the three days of the described events. ${ }^{19}$

When the bride's parents arrive, or more specifically, when they agree that she should stay, the groom bows three times to his future in-laws. There follow negotiations about the conditions for the wedding, i.e. the amount of $k a l y n^{20}$ and some-

${ }_{17}$ Өпкө кагуу (Kyrg.) - Өпкө: lungs (Ûdahin 1965b: 98); кагуу: beating (Ûdahin 1965a: 312).

${ }^{18}$ A large, transparent, plastic sheet is thrown over the couple to protect them from being stained with blood, but at one of the weddings, where the bride was kidnapped with her consent, the bride and groom also stretched out their fingers, so that the woman could touch them directly with the meat.

${ }^{19}$ During the wedding and a few days after it, the bride stays in a part of the room separated by a special curtain (e.g. Borbieva 2012: 145), kôshôgô, kirg. Көшөгө.

${ }^{20}$ Калың (Kyrg.), калым - kalym (Ros.) - material goods to be transferred to the wife's parents by the groom's parents. The matrimonial payment as a total of material or symbolic values, exchanged between the parties or transferred unilaterally, is the result of a corporate 
times about further education opportunities for the young woman, provided the parents give their consent for her to stay. The ceremonial transfer of the kalyn usually takes place within the first year after the wedding and is the main event in shaping the relationship between the two parents of the newlyweds. The kalyn can include both cash and animals, but money should be considered as an animal equivalent. Equally solemn is the handover of the dowry ( $\left.\operatorname{sep}^{21}\right)$ by the wife's family (two to five years after the marriage) (Light 2015: 68-69).

As compensation, bride's parents also receive some money (approximately $10 \%$ of the kalyn, which is not included in the kalyñ's value) - ačuu basar ${ }^{22}$ and the meat of the slaughtered goat. The meat includes ribs - called kesik ${ }^{23}$ (meaning "cut", "a piece" but also doomed, persecuted) - I was told that it was something to exchange for a woman whom God created out of Adam's rib. The word kesik does not solely denote this particular kind of meat, but refers to all ritual leftovers from a feast, for the guests to take home (Light 2015: 63-65).

Once the negotiations are finished, the parents say goodbye to their daughter and leave. They will not be present during marriage celebrations. The meat they received from the groom's family will be eaten by them and their relatives and neighbors. Once it is certain that the young woman is going to stay in the groom's house, she becomes a kelin ${ }^{24}$ - daughter-in-law and is bound by all customary rules of respectful behaviour towards her husband's family.

A. (23 years old): They stole me from the city. I left work and went home (...) they were sitting [in the driveway], a lot of them, my husband, his friends (...) They stole me there. Then I cried, screamed, "I don't want to get married". (...) My mother came, my brother came, they agreed, I didn't agree, my mother agreed, and so I got married (Talas region: S.P. 2014).

and relatives-oriented organization of society (Szynkiewicz 1978: 275-277). Zbigniew Jasiewicz pointed out that kalym cannot be treated as a sale purchase transaction. It not only secures the woman's fate or strengthens her social standing, but also provides an opportunity to gain prestige (Jasiewicz 2004: 118). As Abašyn argues, the evidence that kalym (in Central Asia) has been wrongly understood as "brideprice" is provided by the fact that all the gifts the groom's family gives to the bride's family reflect the value of the dowry that the bride brings into her husband's house. Some scholars have concluded that the dowry is at least equivalent to kalym (Abašyn 2003).

Nathan Light (after of John Comaroff) uses the term bridewealth „to indicate wealth transferred from the kin of the husband to those of the wife. It might be better described as a 'bride gift' because neither the value nor the time of giving are set through negotiations" (Light 2015: 73). However, the negotiations are mentioned by Ismailbekova (2014: 182).

Kalyn also means a dense (e.g., forest) forest, thick, deep (Ûdahin 1965a: 334). Therefore, it always seems to refer to something abundant.

${ }^{21}$ Сеп (Kirg.).

${ }^{22}$ Ачyy бacap (Kyrg.) - the Kyrgyz translate it as "quenching the anger", auyy meaning: anger, something that causes pain (also bitter, sour).

${ }^{23}$ Кесик (Kyrg.).

${ }^{24}$ Келин (Kyrg.) - when she is young everyone calls her kelin. The word signifies the bride, daughter-in-law and a young woman. When she gets older, she will be called kelin only by her in-laws and other senior members of the family. 


\section{Ženeler - the Others at the marriage feast}

Žeñe - the Kyrgyz word for one's older brother's, cousin's or other older relative's wife - on the day of marriage, everybody awaits for the bride's ženneler specifically.

In Kajnar, ženeler could not come on the same day when the kidnapping took place - they arrived the day after the kidnapping. The women came to the ceremony without their husbands and were hosted all night. They were greeted by the elders, but most of the time they stayed in the room where the bride/the couple were. At the beginning, the women introduced themselves to the elders (including the groom's mother), defining exactly their relationship to the bride and then sat down in the hierarchical order, according to their husband's age and status. Later, they received gifts from the family, mainly fabrics. From the moment they had arrived, all activities were focused on them. The women were hosted with great respect, offered the best seats, served copious amounts of food and alcohol, showered with gifts, entertained all night - the hosts made sure that, at all times, they had enough food, drink and a dance partner. Various contests were held, which the žengeler could win, receiving prizes in the form of fabrics, carpets, tableware etc.

The reception and hosting of women was mainly done by women who were the ženneler for the groom (i.e. women married into his family) - they served the food, poured the tea, brought in more dishes, offered presents - and by young married men, the groom's friends and neighbors (they may have been be the abductors), who entertained the guests with conversation, dancing, singing and made sure that alcohol was drunk after every toast. The other guests: the elders and relatives of the groom were celebrating separately in other rooms, keeping an eye on the whole party.

After several hours, new important guests arrived: the so-called "replacement" parents ${ }^{25}$ chosen by the groom's family or by the groom himself for his bride. They were close family friends, neighbors, and were the same age as the bride's parents. As "replacement" parents, they were to help her settle in the new environment. They acted as witnesses at the marriage ceremony. After the food and drinks were served, the nike ${ }^{26}$ marriage took place in the presence of a Muslim priest - a mullah. In a separate room, in the presence of a few witnesses, the mullah read out the prayer, following which all those present (during nike in Kajnar those in attendance were the "replacement" parents, one of the sisters-in-law, two teenage girls who accompanied the bride and myself) took a sip of water from the same cup. Then the wedding bed was prepared. This was done by the women from the groom's family in the presence of the bride's žeņeler, who also gave the bride advice to help her go through her wedding night. Later, the bride and groom were left alone to consummate the marriage. The others continued to celebrate.

\footnotetext{
${ }^{25}$ Өкүл ата, өкүл апа/эне (Kyrg.) - literally: other father, other mother. Ismailbekova uses the term "representative parents" and points out that this function is associated with prestige, authority and respect (Ismailbekova 2017: 84).

${ }^{26}$ Нике (Kyrg.).
} 
S. (35 years old): On the wedding night, husband said that we have to do it quickly, because everyone was expecting it (Talas region: S.P. 2008).

S. (36 years old): He was persuading me for a long time, everyone was waiting to see the sheet. I knew about it and finally I gave up. I was in a lot of pain ... After that, I did not sleep with my husband for 9 months. He didn't push, he said, as long as I don't want to, he won't force me. This is how we lived together for 9 months (Talas region: S.P. 2008).

In the morning, the husband should leave the wedding bed, for it to be inspected by the women of his family in the presence of the bride's ženzeler. There should be traces of blood on the sheet, as evidence of the young woman's innocence. In Kajnar, the sheet was washed and hung in a visible place. After the examination, everyone joined in a feast, there were some more toasts, this time in the company of the elders, who were also present while the bride's žeņeler received their gifts. The women were again offered gifts and money for ensuring the young woman was a virgin. In the end, the ženeler said goodbye to the young wife. Before they left, they placed a large stone to pin down the young kelin's dress while she was sitting down, which was a symbol of the girl's permanent residence in the groom's place. $^{27}$

This marks the end of the marriage ceremony. Everyone returns to their homes and the young kelin stays in the new place, starting a new life. Later, the wedding feast can be celebrated, although it is not necessary, and often it takes place even several months after the marriage day. Both families attend such wedding feast, but even without it, from the first night, the couple is considered to be married and signing relevant official documents is a mere formality that nobody even mentions.

\section{Marriage by bride kidnapping as transformation}

Below, I present an interpretation of marriage by bride kidnapping as the first stage in the social process of 'new-person-making'. I have reached these conclusions inspired by Claude Lévi-Strauss' (2009) structural analysis - approaching the rite of passage as a myth, isolating mythemes from the actions happening during the bride kidnapping and marriage and assigning them to social actors. In this way, I have identified oppositions and their pairs. The result of such analysis revealed a significant similarity to Carlos Fausto's considerations in his "Of enemies and pets: warfare and shamanism in Amazonia" (Fausto 2000: 933-956). Fausto's arguments allowed me to identify more clearly the emerging oppositions and to look at his model in a universal way, as a tool for describing different social practices. For the purposes of my interpretation, I will therefore use the analogies derived from texts about the indigenous peoples of the Amazon

\footnotetext{
${ }^{27}$ Таштын түшкөн жери оop (Kirg.) Let the stone lie where it has fallen.
} 
(Fausto 2000; Buliński 2011). I will look at the phenomenon in question using the category of a 'subject' (understood as a person equipped with the ability to influence other people; agency) and the types of relations the subject establishes with other subjects from the outside world (e.g. animals, animal rulers, ghosts, Whites). In the Amazon, such subjectivity can be acquired through predation (seizure and complete transformation of the Other's subjectivity, e.g. as a result of a hunt and through transformation of an animal into meat) or familiarization (incomplete transformation of the Other's subjectivity, e.g. transformation of wild animals into domesticated animals; pets).

If we apply these categories to the analysis of marriage following bride kidnapping, we see that everything that happens during the marriage ceremony, from the kidnapping and to the departure of the ženneler, constitute specific actions aimed at transforming an Other into someone who enters the circle of relatives, and thus becomes part of a family as a community. The marriage, customarily perceived as a change of social roles, is nothing more than the rite affecting transformation from one status to another. In this case, the transformation involves a kyz (the young woman) turning into a ženze. ${ }^{28}$ It is emphatically not a mere change of roles, but a general transformation.

The transformation starts with the kidnapping. The bride capture is strategically designed and has little to do with romantic elopement. The act itself is carried out by men unrelated to the groom. They are his friends and for them, it is a matter of honour. However, the kidnapping itself is quite dramatic and is an aggressive act resembling a hunt. ${ }^{29}$ The unsuspecting woman is tracked, caught and dragged to the car by force. The kidnapped woman resists, defends herself and screams, but men overpower her, so as to take her to her future husband's house against her will.

There she is placed in the care of women, who will attend to her directly most of the time. They force her to put on a headscarf and to sit down ${ }^{30}$ - i.e. to accept that she is to become a kelin. The women are many, and when one cannot manage, she calls others to help her. The important thing is that these women are not related to the groom either. His mother, sisters or cousins are not present during these activities. All these tasks are handled by the groom's ženneler - women married into his family - i.e. wives of older brothers, distant and closer cousins. Although the women often forcibly put the scarf on the young woman's head,

\footnotetext{
${ }^{28}$ Brothers' wives are абысындар (pl. abysyndar) for each other. The wives of the brothers are termed abysyn; the younger members of the patriline would address their brothers' wives "ženne". These both terms, are used as both labels and address terms (Ismailbekova 2017: 71-72). The bride will also be called kelin - daughter-in-law. Out of all other relational terms for a woman married into a family I chose žeñe, exactly because I wish to highlight that it is all about transforming the bride into the same kind of person as the other women who married into the family. ${ }^{29}$ This does not mean that a woman is the "prey", but that the relationship to her position is the same as that of predator towards its prey.

${ }^{30}$ The expression "she sat down" means that the girl stayed in the abductors' house as a wife and a daughter-in-law.
} 
against her will, I call their actions 'pro-social', because they aim to make her one of them - a žene that is part of their family.

Finally, there are the bride's ženneler, whose presence is prominent during the marriage ceremony. ${ }^{31}$ They too, as married into the family, put indirect pressure on the bride, they come to attend the bride's wedding night, and they are hosted by the groom's ženneler, who personally offer gifts to the women who arrive, and serve them food and drink. When bride's žengeler arrive, they are greeted by the groom's ženzeler.

In Kajnar, apart from them, those present included groom's other friends and the abductors. They were the ones who feasted at the table with the žeñeler and, like them, they came to the marriage ceremony without their spouses. The whole process was a bit like seduction. The men entertained the women at the table, made sure they eat the food, sang to them and encouraged them to sing, danced with them, kept close and tried to get them drunk. However, all the time they addressed them as "ženne", thus honoring the rules of honorific etiquette.

All this happens in the presence of the bride and because of her. Bedding for the wedding night is prepared by the groom's žeñeler, while the bride's žeñeler talk to her about the wedding night. After the wedding night, all of the žeñeler are present during the inspection of the sheet, and the groom's ženneler hand over the money to the bride's žeñeler, rewarding them for her sexual innocence and virginity preserved until the wedding day. Finally, the bride's žeñeler pin down her dress with a stone. In this way, they finally say goodbye to her. From now on, she becomes for them a different category of a person. Until now, she was only the sister of their husbands, but because she got married herself, she became their potential co-mother-in-law ${ }^{32}$ or matchmaker, ${ }^{33}$ since their children will be able to marry. ${ }^{34}$

I called the whole process of transforming the Other into someone who will become one of the new family's affines - "familiarization". Just as bride kidnapping resembles a hunt, all the acts aimed at preparing the young woman to live with a new group resemble domestication of a wild animal. ${ }^{35}$ Women dress, caress, comb and comfort her. However, they do not let her go and they act consistently and firmly. In this way, the young woman turns from "prey" into a member of the community. The familiarization is mainly done by women who, like her,

\footnotetext{
${ }^{31}$ Sometimes, for example, when the distance between the new home and the family home is very long, žene do not come.

${ }^{32}$ The son's wife's mother (for the matchmaker).

${ }^{33}$ The daughter's husband's mother (for a co-parent-in-law).

${ }^{34}$ Kinship is here considered to derive from the male line - from the father (patrilinear). Children born to sisters or siblings will not be considered as related by kinship, as they belong to two different families. Kinship and membership in the same family will only occur between brothers' children - as the children's fathers will have the same father.

${ }^{35}$ A comparison to taming can be found in the rough words of men in Butts's film "Kidnapped Brides", according to which the girl is like a foal, she knows nothing about life. "Of course, when she gets married, she'll cry and fight and resist. But when she's been broken and harnessed, she'll become obedient lake a good horse and then she'll be happy" (Butts 2009).
} 
have been transformed, have become family members. Just as I have dubbed female actions 'pro-social', the aggressive male action - kidnapping is 'anti-social'. I put these words in inverted commas, because I realize that all activities undertaken by members of the community are social activities, but I divide them into those characterized by aggressive/destructive forms and those that socialize/ transform somebody into an active and adaptable member of the community. Both forms of action lead to the same goal - "obtaining" a new family member. This is a group effort by both genders and under no circumstances we can say that everything that happens in connection with bride kidnapping is purely led by men and that only men are responsible for it. Indeed, it is mostly men who carry out the act of kidnapping, but it is only part of the whole process of creating new social ties, which starts with the rite of passage - the marriage ceremony. However, before the bride is kidnapped, it is women - the ženeler - who most often become people searching for candidates for wives for their husband's family members. To summarize, it is men who perform "predatory" actions outside (home) towards the Other individual ( $k y z)$. The Other is being "familiarized" by the women inside (house). In this way, the $k y z$ becomes a familiar Other - part of the community (one of the familiar Others - ženge). As a ženge, she will then go beyond the sphere of the interior, in order to find a new ženge and use the men to obtain her from the outside.

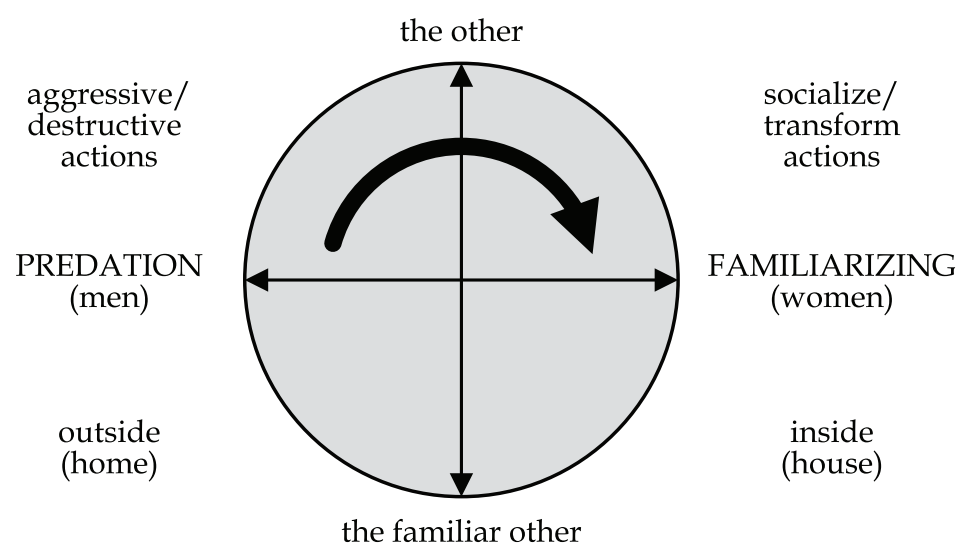

symbols used:

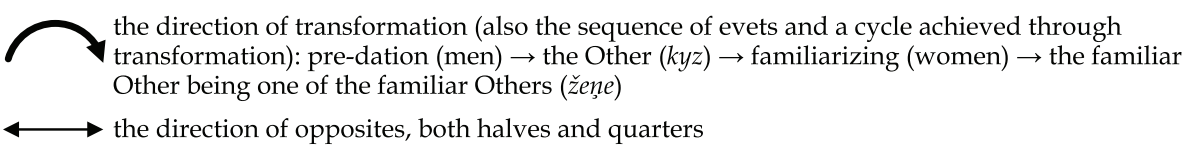

DIAGRAM 136: A woman's transformation cycle

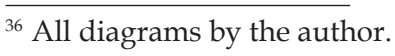


If we approach the rite of passage, i.e. the marriage ceremony, as a myth that has its message, the whole process of "obtaining" a new affine can be presented using the diagram depicting the cycle of a woman's transformation process (Diagram 1). Through actions of both women and men: from being THE OTHER to being an affine - THE FAMILIAR OTHER.

During the marriage ceremony, women and men act both individually and collectively, and these actions stand in opposition to each other (Diagram 2): men kidnap a woman and slaughter a goat, and these actions are undoubtedly associated with aggression and I describe them as predation. At the same time, they are necessary for the transformation to take place and lead to a change in the existing social structure. This is achieved through the actions of women who make sacrifices (Diagram 3). In both cases, the sacrificial "object” are handed over to women to make what was anti-social into social.

The structural correlation between the goat and the bride is evident in several respects. The purpose of killing the goat is, firstly, to make it an instrument of blessing (the old woman blesses the couple with the animal's lungs), so that its blood can contribute to the couple's fertility, and secondly, to consume it. ${ }^{37}$ Nathan Light suggests that this ritual should be associated with purification and bringing the kelin into the home safely and purely. The ritual is combined with another one that he observed in the same region (Kara-buura). The salt ritual involved a small bowl of salt and ash mixed, passed around the woman's head, just before she was taken into the house for the first time - which was explained as a purification (Nathan Light, private correspondence). As mentioned above, when touching the young couple, the old woman pronounced: May you have cattle in front of you and children behind you. This is an expression of the wish for fertility not only in terms of offspring, but also the prosperity in the form of abundant cattle.

Women make food from raw meat. They wash the blood off the pieces, process them and serve them as food. Thirdly, for the goat to become a gift - to give its meat (ribs) to the woman's parents. This was clearly emphasized through the analogy to the creation of Eve from Adam's rib. Just as the goat is transformed into a fertility tool, the young woman from the outside is transformed into a family member - also a fertility tool. Her defloration and her blood on the sheet denote the first attempt to fertilize and thus to maintain the family.

\footnotetext{
37 This ritual is also mentioned by Fiel'strup, noting that the lungs were later thrown to the dogs and the goat meat given to the poor (Fiel'strup 2002: 28-29). Throwing out the lungs used for the blessing may indicate the cleansing function of the ritual, but the author himself also links it with fertility. Interestingly, he also states that in Chuy Kirgiz, after a woman gave birth, the placenta was also thrown to dogs, so that in the future she would have as many children as there are puppies in a litter (Fiel'strup 2002: 44-45).
} 


\begin{tabular}{|l|l|}
\hline \multicolumn{1}{|c|}{ MEN (collective action) } & \multicolumn{1}{c|}{ WOMEN (collective action) } \\
\hline ANTI-SOCIAL ACTION & PRO-SOCIAL ACTION \\
\hline YOUNG WOMAN'S CAPTURE & YOUNG WOMAN'S TAMING \\
\hline KILLING THE GOAT & PREPARING THE MEAL \\
\hline \multicolumn{1}{|c|}{ MAN (individual action) } & WOMAN (individual action) \\
\hline DEFLORATION & BLESSING \\
\hline
\end{tabular}

DIAGRAM 2: Oppositions

YOUNG WOMAN'S

CAPTURE

AGRESSION

KILLING THE GOAT

AGRESSION
HANDED OVER TO WOMEN

HANDED OVER TO WOMEN
TRANSFORMATION

TAMING (OTHER INTO

A FAMILIAR OTHER)

TRANSFORMATION

FROM RAW MEAT

INTO FOOD

DIAGRAM 3: Transformation

YOUNG WOMAN - offering/prey (as the captured person, during

a hunt - kidnapping)

GOAT - offering (as sacrifice - blessing and food offering and meal)

GOAT (offering)

blood (fertility) $\longrightarrow$ transformation $\longrightarrow$ offering

blessing (old woman)<smiles>[CH]1[CH]CC1</smiles>

YOUNG WOMAN (offering)

offering $\longrightarrow$ transformation $\longrightarrow$ blood (fertility)

defloration (the groom)

DIAGRAM 4: Offering

Structurally, it appears that the goat and the young woman are the same offering (Diagram 4) and the former is an extension of the latter. When the woman is kidnapped and brought to the groom, the goat is killed and its blood is used to mark the young couple. Through the blood of the goat, which is a blessing aimed at ensuring fertility, an exchange of sacrifice takes place. The goat's ribs are given to the bride's parents (instead of returning the daughter), and the bride becomes the offering (the parents order her to stay) and is marked with her own 
blood through defloration, which is also the first attempt at fertilization. Henri Hubert and Marcel Mauss in their Sacrifice: Its Nature and Function wrote that the one who makes an offering is the one who awaits the return from the deed (Hubert, Mauss 2005). In this case, the expected 'return' is fertility.

Goat meat is not just offered in exchange for the young woman, because animals, as Light notes, have a ritualistic value - they develop and maintain social ties. Animals as gifts, especially when given as meat, are an expression of appreciation for the person who receives the gift. Pieces of meat, other food and drinks served in the specific contexts of the feast evoke common positive feelings and maintain human bonds (Light 2015: 52-55). The first offering of goat meat is, therefore, the initiation of mutual bonds and further exchanges. The material substance of animals gains in value when it circulates and is used as part of symbolic rituals (Light 2015: 68).

\section{Žeñe - the Other inside the family}

Žeñe is not any kind of sister-in-law, but one who is a person specifically linked to seniority, and therefore needs to be shown respect. It is, therefore, not insignificant that it is žengeler who are invited to the marriage celebrations and that they are women of reproductive age, i.e. relatively young. Finally, and perhaps most importantly, it is significant that they are not related to the family of the bride, nor to the bride herself. They are the Others, but through the ongoing 'process of being' within the family they are part of it, they are like the bride, whose 'process of being' within the new family begins on the day of the marriage ceremony.

The day when she gets married is a turning point in a woman's life. I deliberately avoid mentioning the groom here, as the most significant changes, manifested to be visible to the community, affect the young woman. First of all, her loss of virginity is publicly noted. Secondly, since she gets married, she is referred to as a kelin, is expected to wear a headscarf and dress in a way that will not offend her in-laws. Her place of residence shifts to a new home. The newly wed husband is still called žigit, ${ }^{38}$ no one mentions his sexual life, he does not change his attire nor residence. The bride is an absolute stranger, she is the new kelin, and so she holds the lowest possible status within the groom's family. She does not have her things, she may not know anybody in that family, but needs to show respect to everyone. When her žengeler say goodbye, she starts a new life as a kelin among her husband's ženeler, as one of the abysyndar - sister-in-law. The young kelin is also a žeñe and when her husband's younger sister or cousin gets married, she may be asked to represent the family during the marriage. If her husband's family kidnaps a bride, she and the other abysyndar will have to take care of the new kelin and host her žeñeler during the marriage ceremony.

\footnotetext{
${ }^{38}$ Жигит (Kyrg.) - signifies a young, brave and agentive man and the groom, the meaning is always positive.
} 
During my stay in Kajnar I have spent some time with such women. One of them was the groom's sister-in-law (his ženne), who was also kidnapped a few years ago. My host's sister-in-law told me about this, laughing: She also cried as much as $M$, and now she would not dream of leaving this house even if they pulled her with a tractor. The other woman answered by pointing to the first one: She was the one who kidnapped me. My interlocutors often referred to the perpetrators of the bride kidnapping as "them" - having in mind the particular family, and not a single person, ${ }^{39}$ or by saying "we kidnapped her" - when referring to a daughter-in-law or sister-in-law.

The ženelerler present during the marriage ceremony are key people, precisely because they are invited to attend. All the activities during the wedding reception seem to be focused around the žeņe guests. They are offered attention and respect, although in everyday life their status at ceremonies is diametrically different from the one they enjoy on the day of their affine's marriage. At all family and social events everyone is assigned a specific place, depending on age, social position and gender. The most important seats are always occupied by men and elderly people, while young married women sit in less honorable spots, far from the "front of the table". Even if they are guests themselves, they serve other guests. In this one case, i.e. during the marriage ceremony, young women guests - ženeler, not only arrive without their husbands, but they are also seated in the most important places (according to the status and the age of their husbands). However, everything is still in line with the accepted norms.

In Kajnar, the older family members feasted in other rooms. The head of the killed animal (i.e. the greatest honour ${ }^{40}$ was offered to the most important man of the groom's family. The family elders visited the bride and groom's room only rarely, and only for the most important moments of celebration. The bride's closest family generally arrived only to tell the bride that she was to stay, and to settle financial matters with the groom's family.

Here, I do not wish to ignore the priority role played by the parents in the matrimonial affairs of their children - as mentioned by Borbieva (2012: 144) and Mroczkowska (2018: 288-291) - but I want to highlight what is actually happening around the captured bride and to describe those aspects that I have observed during my research, but have not found in other studies. The groom's family also came for only a few specific moments during the whole event and they were always far removed from most of what was happening in the bride's presence. The most active part was played by the people who were not directly related to either the bride or the groom.

What happens during the marriage day, and even before it, involves otherness. The bride is often selected by the groom's women affines, she is kidnapped by his friends, and the blessing is bestowed by an unrelated elderly woman. The marriage feast during the night is hosted by the groom's affines and those

\footnotetext{
${ }^{39}$ Men tend to say that it was them who kidnapped wives.

${ }^{40}$ This is the case in the Talas Region. The etiquette for carcass cutting and meat division for individual guests varies in different regions.
} 
being hosted are the bride's affines. The groom's friends entertain the bride's affines. The groom's friends/neighbors, who are not related to the groom's family, are chosen as 'replacement' parents to witness the Muslim marriage ceremony.

The bride becomes the focus of Otherness. The marriage triggers her transformation into a žene, the process of being in a new social system. From that day on, she will be one of the abysyndar - sisters-in-law, she will also be a kelin and a ženne. ${ }^{41}$ For some people, she will be a kyz - a "girl", until the end of her life. The transformation from a kyz into a žeñe goes much deeper than just an alteration of the social role. Žene appear at the marriage ceremony and during the feast in a two-fold way - first as the female affines (Others) of the groom, and secondly, as the female affines of the bride. The otherness we see here involves three levels: women married into the family (on both sides) and the young woman as an individual Other. The Others as women unrelated to the families have a central role to play during the marriage ceremony: the bride's ženneler transfer her to the new family through the groom's ženneler, who make her "their own Other" (through familiarization, she becomes like them). The women married into the family, although they work for the family's benefit, do not belong to the family and their otherness will be maintained through customs, even though it will undergo changes with age and subsequent stages of life. Such otherness, however, is a transition from duality - individual (the captured Other)/collective (women married into the family) - to unity (our/own Others). This happens through the transformation that starts on the day of marriage and continues throughout the woman's life. She will remain the Other for a long time, and this status can only change if she outlives all the members of her husband's family born before the day of her marriage. Her status involves a process - it will become higher as the woman gets older and "gains" respect. Her otherness will diminish with time and age. Once again, I wish to return to the diagram representing the cycle of the woman's transformation process: women married into the family, who are not from the family and so are "from the outside" - the familiar others - look for potential wives for their husband's family. The men "from the outside", unrelated to the groom, kidnap the young woman and hand her over to the women who are "inside" - they are part of the community for whose benefit they act. They are married, they wear headscarves and by their actions they persuade the young woman to become like them - the familiar other. Through disempowerment and familiarization, they constitute a "new person" - the Other "just like us".

\footnotetext{
${ }^{41}$ It is worthwhile to think of these roles as positions in relationships.
} 


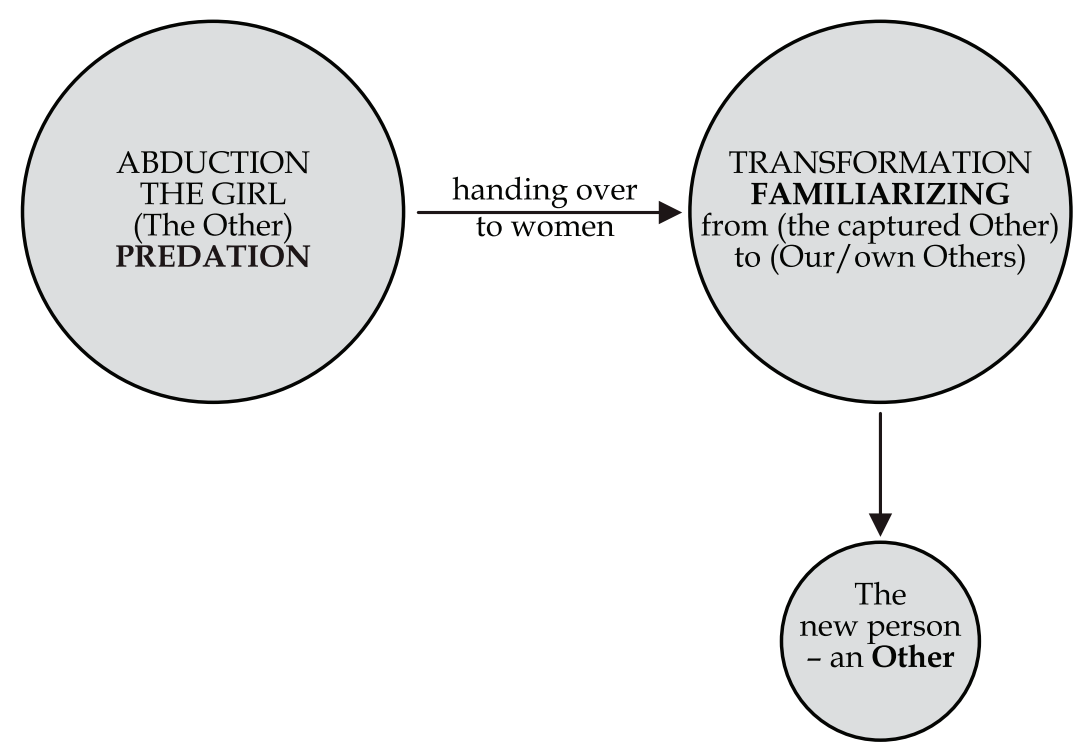

DIAGRAM 5: Familiarizing

\section{Maintaining otherness}

The term kelin comes from the verb kelùù ${ }^{42}$ (to come and enter), because usually young brides move from their birth families to their husbands' families (Ismailbekova 2014: 383).

Kelin, above all, must show respect (Ismailbekova 2014: 379, 2017: 83). A visible manifestation of respect towards one's in-laws is conveyed by proper dress and behaviour. She should bow to her mother-in-law and her husband's older family members (Ismailbekova 2014: 379). The bowing is sometimes a simple nod, but more often she has to bow low - making a movement that takes enough time and is expressive enough for everyone to see. "'Grooms' mothers are instrumental in making sure that their daughters-in-law behave appropriately in this patrilineal context" (Ismailbekova 2014: 379).

S. 35 years old: For ten years, I bowed low to my mother-in-law, at the waist - as a sign of respect-every time I saw her, and she greeted me and wished me happiness and a long life. Now I only bow to her when I don't see her for a few days (Talas region: S.P. 2008).

Kelin, if she has been kidnapped, quite suddenly starts living with a man she often does not know, in a completely new house, among strangers. She rarely sees her parents. During the day she mainly stays with her husband's other sisters-inlaw or his younger sisters, doing house chores. As long as she lives with her

${ }^{42}$ Келуч (Kirg.). 
in-laws she is obedient to them, in the same way she has been obedient to her parents before. She performs her mother-in-law's most duties, but for a long time she keeps a distance from her husband's parents, especially from her father-in-law, with whom she is not even allowed to sit at the same table. She should not shake his hand, look into his eyes or talk to him..$^{43}$ A similar interdiction relates to her husband's older brothers. Everybody knows what is expected of a kelin. The bride is also not allowed to sit with her back to them, sit with her leg outstretched speak loudly or sharply, walk bareheaded or barefoot (Ismailbekova 2014: 379).

In the first stage of marriage, or rather in the early stage of life within the new family arrangement, the main point is to visibly show respect for one's in-laws. It is important for a young kelin "to know how to behave" in any given situation; she needs to be present, helpful and, at the same time, invisible, by which she provides the opportunity for others, namely her in-laws, to whom she needs to show respect - to be visible. One of the women said about her daughter-inlaw: My daughter-in-law lives with us. She is a good wife and a good daughter-in-law. My husband also likes her; how she cooks and works. And she helps me even more to please him (Talas region: S.P. 2008).

During the marriage feast, the bride does not prepare meals, she does not pour tea, she sits in the most honored place, surrounded by her ženneler, and is served by her husband's žengeler. When she becomes a kelin, it is her duty to prepare meals and serve them to guests (Pritchard 2009: 85). Often, the obligation to help also passes on to the older kelin, who are at a different stage of their life in the family as they are "gaining" respect. The new kelin has obligations not only towards her in-laws but also towards her husband's older brothers, whom she is expected to treat in a similar way as she approaches their father. If an older brother is holding a party, the wives of his younger brothers - kelin are obliged to help his wife. She is the hostess, she sits at the corner of the table and pours tea, while the younger kelin work in the kitchen. The daughter-in-law shows her respect to her in-laws by wearing appropriate kelin clothes. Above all, she should wear a scarf on her head, the most important attribute of a married woman. She should also wear a skirt or a dress. Wearing trousers (without a skirt) violates accepted standards of attire appropriate for a young married woman. ${ }^{44}$ The kelin's status at home is the lowest. She cannot address her husband's family members by their first names, but calls his parents $a p a^{45}$ (mother) and $a t a^{46}$ (father), his older sisters $\check{e} \check{z} e^{47}$ (older sister), his younger sisters $k y z$ (girl), his older brothers $a k e^{48}$

\footnotetext{
${ }^{43}$ These customs have been present among the Kyrgyz people for a long time; similar prescriptive norms and interdictions are described in „Kyrgyzy. Ėtnogenetičeskie i ètnokul'urnye processy w drewnosti i srednowiekov'e w Central'noj Azii" (Moldlobaev, Pirimbaewa 1996: 89).

${ }^{44}$ The most common clothes consist of cotton, knitted or suede sets of matching trousers and knee-length tunic (usually in various shades of red, pink and purple).

${ }^{45}$ Апа (kir.) - mother, a form of address used for an older relative.

${ }^{46}$ Ата (Kyrg.) - father, ancestor.

47 Эже (Kyrg.) - older sister, for of address for a woman older than ego.

${ }^{48}$ Аке (Kyrg.) - older brother (also father) another form ага (Kyrg.) - older brother, pal, friend, uncle, older relative.
} 
(older brother), his younger brothers bala ${ }^{49}$ (boy). ${ }^{50}$ As it is also not allowed to say the names of family members in their absence, when speaking about them, she must find an expression which, without saying the name, will indicate the appropriate person (Ismailbekova 2014: 378-379). Restrictions related to family members go even further. She may not address by name those members of her husband's family who were born before she married into the family. Even if a child is born the day before the new kelin's marriage, she will always address them kyz or bala. A young married woman is expected to have a child as soon as possible, preferably within a year of getting married. If the couple does not produce a child after one year, they will increasingly experience social pressure to do so. The issue is discussed not only by the immediate family, but by the whole community. One woman told me that if a kelin does not bear a child within two or three years after her marriage, her husband has the right to send her away. Another woman mentioned the difficulties she experienced: For two years I could not get pregnant, I was treated in the hospital and his [husband's] family were against me. They urged him to send me home, but he did not listen to them.

The respect shown by a kelin as the Other in the husband's lineage has a twofold meaning. First, it "reminds" everybody of her status - even though she is part of the family, she does not belong to the family. Secondly, and as a consequence, due to the fact that she is a 'familiar Other', she can host and effect transformation of the new kelin in her husband's family.

In addition to the labor provided for the benefit of the family members, it is good if the kelin is also actively involved in social events related to the life cycle. As a ženne, she has a social responsibility to carry the dowry of her daughters from the countryside to the groom's family and to welcome other young brides to the village during their wedding. She will be the first to tell the families of newly brought brides that their daughters are virgins and who will see the potential grooms first. For social tasks and active involvement, she will receive money and various gifts (Ismailbekova 2015: 384).

\section{Transformation and gaining respect}

Family and social life in a Kyrgyz village is perceived through the lens of respect. ${ }^{51}$ A woman develops her position within a family to whom she shows respect in her old age she is respected if she herself was hardworking, raised children and got them married. When I collected women's stories, ${ }^{52}$ their sparingly told

\footnotetext{
${ }^{49}$ Бала (Kyrg.) - child, infant, boy, son, grandson.

${ }^{50}$ The forms of address used within the family are age-related. Younger siblings address the older siblings by using terms for older brother, older sister (like kelin), sometimes adding their first name. older siblings call the younger siblings by their first names.

${ }^{51}$ Mroczkowska identified two categories: shame and respect (Mroczkowska 2010), while in her 2018 publication she claimed that "the Kyrgyz world is mainly described using the categories of tradition, respect, honour and shame" (Mroczkowska 2018: 272).

52 The following diagrams are based on the stories of 20 women.
} 
life stories focused on education, dreams, marriage and present life. All these stages of life were subordinated to the family, which I called the centre. The centre is a household linked to family and lineage, and a given person acts to benefit it. In her article "Constructing the authority of women through custom: Bulak village" Ismailbekova described case studies illustrating how women gain authority (or when Kyrgyz family ideals are violated) by meeting all the norms of Kyrgyz family ideology and creatively negotiating strategies within the patriarchal system (Ismailbekova 2015).

During a woman's life, the centre to which she has to submit, or in which she ultimately becomes the one who is subordinating, changes three times. At first, she lives with her parents, obeys them and shows them respect. Later, when she pursues education or finds work without being married, she is still subordinate to the will of her parents and their home is her centre. When she gets married, her husband's family home becomes her centre. She works for the household's benefit and is supported by the income generated by it. She needs to be even more obedient than in her parents' house. As a young kelin, she is subject to a wider scope of norms ${ }^{53}$ and she needs to behave accordingly. The norms are primarily focused on showing respect to the in-laws, who are the most prominent representatives of the centre, as well as decision-makers. When the woman gives birth to her first child, she usually moves with her husband to a separate home and starts to run a separate household. She will remain subordinate towards the husband's family (the centre - the "big house") for many years and the degree of her subordination will be inversely proportional to the respect that she has "gained" (becoming a centre for others: her children and later her daughters-in-law).

Ismailbekova comes to another noteworthy conclusion - that the status of a young wife depends on how well she is doing in her parents-in-law's home, and that the husband's status depends on his wife's socialization in rural social life (Ismailbekova 2014: 385).

\footnotetext{
${ }^{53}$ The new kelin's status is the lowest within the family, and she is expected to show respect to all family members. In her own family, she used to follow mainly the rules of age seniority, which are for her a natural part of everyday life. When she starts living in the new place, she needs to familiarize herself with the new rules.
} 


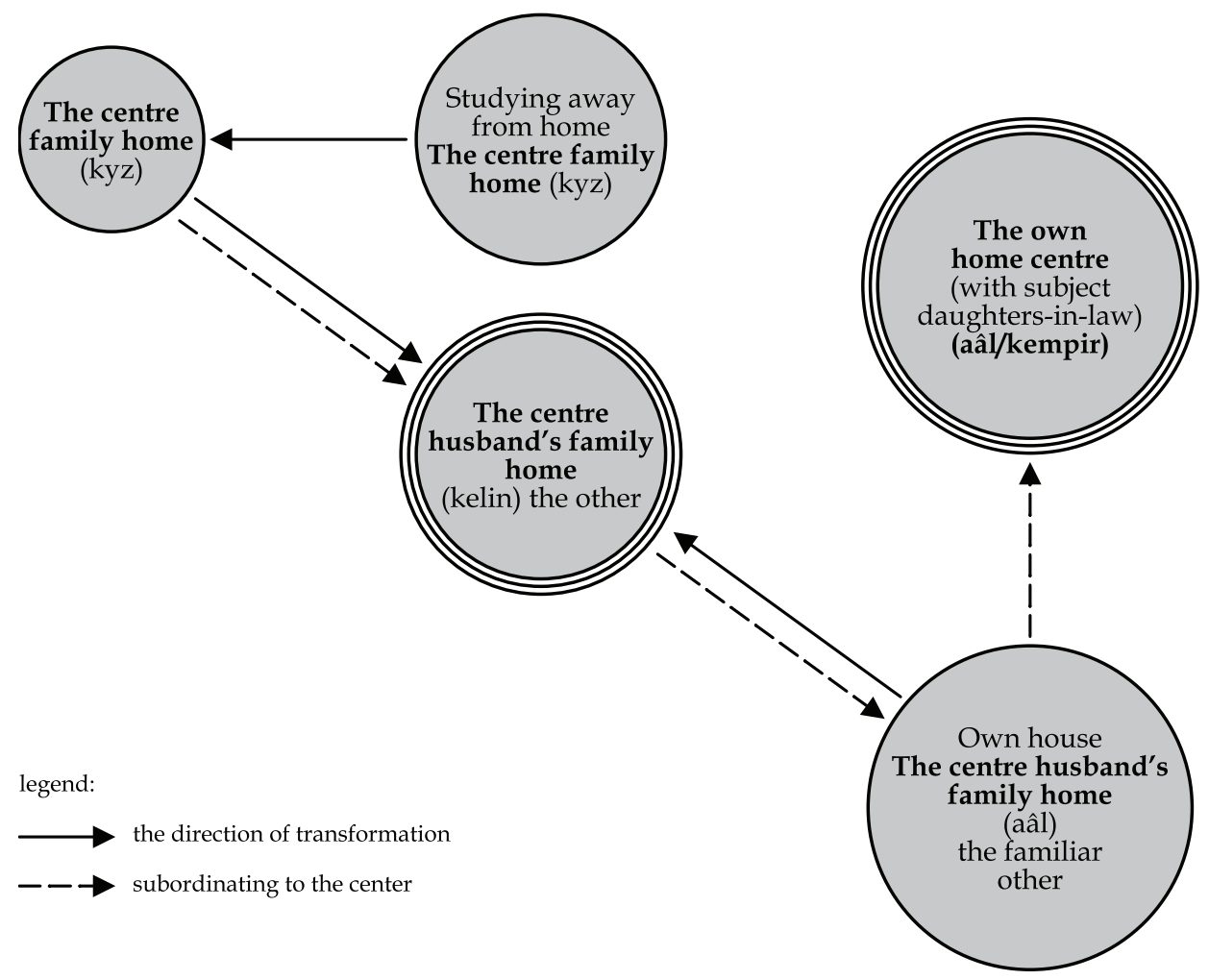

DIAGRAM 6: Subordinating to the center/becoming the center

A little girl $(\mathrm{kyz})$ is subordinated to the centre and obeys her parents' will. Later on, when as a young woman she gets married, she becomes a daughter-inlaw (kelin) - she loses her status as a subject, assistance and obedience towards the new centre are more affirmative than in the household where she grew up. As time passes, if she shows respect to others, bears children, she will become responsible for her household and will gain the status of an âal. ${ }^{54}$ Her position slowly changes and at the right moment, she will have her own kelin, who will show her respect. She will become a kempir, ${ }^{55}$ a well-respected old woman sitting in the best spot, to whom daughters-in-law bow and for whom they do most chores, while family members and the community at large ask her opinion (Diagram 6 and 7).

$$
\text { kyz } \longrightarrow \text { kelin } \longrightarrow \text { â̂l } \longrightarrow \text { kempir }
$$

DIAGRAM 7: The stages of life

\footnotetext{
${ }^{54}$ Аял (Kyrg.) - woman, wife, spouse.

${ }^{55}$ Кемпир (Kyrg.) - old woman.
} 
Ismailbekova presents a similar model, revealing a more complex image of the role of women in Kyrgyz society than the one present in the general discourse of national patriarchy. The authority and power of women are realized through their successive roles as bride - kelin, mother - apa and mother-in-law kajnene. ${ }^{56}$ However, the construction of authority is not easy. It is a rather complex process involving many factors, such as Kyrgyz family ideals, age, reciprocity and the individual's ability to engage effectively in "patriarchal negotiations" (Ismailbekova 2015).

\section{Conclusions}

In this article I have presented a model of marriage by bride kidnapping, based on the analysis of descriptions and ethnographic observations I made during my fieldwork, focusing on the actions of specific individuals. This model revealed that the main social actors during the marriage ceremony are unrelated to the newlyweds: they are friends and neighbors of the groom, and the bride's and groom's affinal kin. The kidnapping and marriage, as well as a number of activities that precede it, show that the act of kidnapping is part of a social process and collective activities of the whole community that is involved in it. The marriage, the offering of meat from an animal slaughtered and used for blessing is also the beginning of bonds and sustained exchanges and relationships between families.

In my analysis I focused on the dynamic relationships between otherness and familiarization, which involves the making of a familiar Other (just like the other familiar Others). These relations consist in the appropriation of the Other's subjectivity, whereby the Other must be disempowered and then familiarized in order to be used in the process of making new subjectivities. These subjectivities are created on three levels:

1. The transformation of the Other into the familiar Other, who with time will acquire new subjectivity.

2. Fertilization, giving birth and raising offspring.

3. Acquisition and creation of new subjectivities by the familiar Other through participation in marriages by bride kidnapping.

I have presented this process through the cycle of a woman's transformation by identifying the actions by groups of people: the predatory/anti-social actions of men and the familiarizing/socializing actions of women. The activities involved in the act of bride kidnapping mark the beginning of the process, which will later be perpetuated by the kidnapped bride herself. Both types of action: predatory and familiarizing are performed in collaboration, with oppositions leading from duality to unity. The term "familiarizing predation", used by Fausto (2000), fully illustrates this collaboration (Diagram 7).

\footnotetext{
${ }^{56}$ Кайнене (Kirg.).
} 
predatory/anti-social familiarizing/socializing

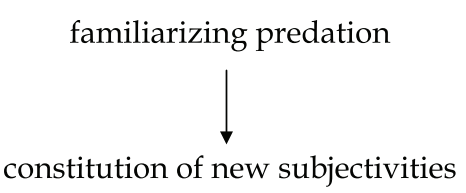

Diagram 7: Constitution of new subjectivities by familiarizing predation

In the next stage of her life in her husband's family home, the woman continues to acquire subjectivity and to procure new ones. The final conclusion is that the custom of bride kidnapping triggers the constitution of a new subjectivity a 'new person'. This process, in turn, is a way of social reproduction of families, which takes place through the acquisition, familiarization and constitution of subjectivity resulting from collective agency of all the family members.

Acknowledgements

I would like to thank Tarzycjusz Buliński, Paweł Chyc, Magdalena Chułek and the translator Katarzyna Byłów for comments and suggestions regarding the earlier version of the article. I express my gratitude to the anonymous reviewers and to Nathan Light who provided excellent comments. I am also grateful to Mariusz Kairski for his scientific support.

Transl. Katarzyna Byłów

\section{Bibliography}

Abašyn, S. (2003). Kalym i mahr w Srednej Azii: pravo ili rytual. Otečestvennye zapiski, $5,428-435$.

Abramzon, S.M. (1990). Kirgizy i ih ethnogoneticheskie $i$ istoriko-kulturnye svyazi. Leningrad: Nauka.

Aitpaeva, G.A. (2007). Mazar Worship in Kyrgyzstan: Rituals and Practitioners in Talas. Bishkek: Aigine Cultural Research Center.

Amsler S., Kleinbach, R. (1999). Bride Kidnapping in the Kyrgyz Republic. The International Association of Central Asian Studies, 4.

Antoniskis, A. (2013). Bridal Kidnapping: A Kyrgyz Method of Marriage. Human Rights Brief, 20/2, 49-50.

Borbieva, N. (2012). Kidnapping Women: Discourses of Emotion and Social Change in the Kyrgyz Republic. Anthropological Quarterly, 85(1), 141-169.

Buliński, T. (2011). Ludzie, zwierzęta i inne byty w świecie Indian Amazonii. Wstęp do perspektywizmu. In: A. Mica, P. Łuczeczko (eds.), Ludzie i nie-ludzie. Perspektywa 
socjologiczno-antropologiczna (pp. 89-114). Gdańsk: Wydawnictwo Orbis Exterior Uniwersytetu Gdańskiego.

Fausto, C. (2000). Of enemies and pets: warfare and shamanism in Amazonia. Transl.

D. Rodgers, American Ethnologist, 26/4, 933-956.

Fenzel, B. (2009). Mothers-in-Law on the Doorstep. Max Planck Research, 3, 88-95.

Fiel'strup, F.A. (2002). Iz obrâdovoj žizni kirgizov načala XX veka. Moskva: Nauka.

Handrahan, L.M. (2000). Implications of International Human Rights Law and Bride Kidnapping in Kyrgyzstan. PRAXIS The Fletcher Journal of Development Studies, 16/3, 1-13.

Handrahan, L.M. (2004). Hunting for Women. Bride-kidnapping in Kyrgyzstan. International Feminist Journal of Politics, 6/2, 207-233.

Hubert, H., Mauss, M. (1981). Sacrifice: Its Nature and Functions. Transl. W. D. Halls. Chicago: University of Chicago Press.

Ismailbekova, A. (2014). Migration and patrilineal descent: the role of women in Kyrgyzstan. Central Asian Survey, 33/3, 375-389.

Ismailbekova, A. (2015). Single mothers in Osh: Well-being and coping strategies of women in the aftermath of the 2010 conflict in Kyrgyzstan. Focal. Journal of Global and Historical Anthropology, 71, 114-127.

Ismailbekova, A. (2017). Blood Ties and the Native Son. Poetics of Patronage in Kyrgyzstan. Bloomington: Indiana University Press, Kindle Edition.

Israilova-Har'ehuzen, Č.R., Ǎgafova, E.A. (1999). Sravnitel'nyj analiz nomenklatury terminov $i$ sistemy rodctva u cevernyh kyrgyzov $i$ čuvašej. Biškek: Tehnologiâ.

Jasiewicz, Z. (2004). Kierunki przemian rodziny w Azji Środkowej. Na przykładzie Uzbekistanu i Afganistanu. In: Z. Jasiewicz, Rodzina, społeczność lokalna i grupa etniczna w Polsce i Azji Środkowej (pp. 113-123). Poznań: Wydawnictwo Poznańskie.

Kleinbach, R., Ablezova, M., Aitieva, M. (2005). Kidnapping for Marriage (Ala Kachuu) in a Kyrgyz Village. Central Asian Survey, 24:2, 191-202.

Kleinbach, R., Salimjanova, L. (2007). Kyz Ala Kachuu and Adat: Non-consensual Bride Kidnapping and Tradition in Kyrgyzstan. Central Asian Survey, 26/2, 217-233.

Kleinbach, R., Babaiarova, G. (2013). Reducing non-consensual bride kidnapping in Kyrgystan. Eurasian Journal of Social Science, 1(1), 50-60.

Kochanek, E. (2017). Azja Centralna - rosnący w siłę dostawca surowców energetycznych. Zeszyty Naukowe Akademii Sztuki Wojennej, 4/109, 99-127.

Kuchumkulova, E.M. (2007). Kyrgyz Nomadic Customs and the Impact of Re-Islamization After Independence. Ph.D. Dissertation, Department of Near and Middle Eastern Studies, University of Washington.

Leo, C.C (2013). Marriage in Form, Trafficking in Content: Non-consensual Bride Kidnapping in Contemporary Kyrgyzstan. Ph.D. Dissertation, University of Chicago.

Lévi-Strauss, C. (2009). Antropologia strukturalna, transl. K. Pomian. Warszawa: Wydawnictwo Aletheia.

Light, N. (2015). Animals in the Kyrgyz Ritual Economy: Symbolic and Moral Dimensions of Economic Embedding. In: S. Gudeman, C. Hann (eds.), Economy and Ritual. Studies of Postsocialist Transformations (pp. 152-178). New York, Oxford: Berghahn.

Moldlobaev, I.B., Pirimbaewa, Ž.Ž. (1996). Kyrgyzy. Ètnogenetičeskie iètnokul'turnye processy w drewnosti i srednowiekov'e w Central'noj Azii. Biškek.

Mroczkowska, J. (2010) Kirgiskie małżeństwa przez porwanie - doświadczenie czasu, kolektywności i przemocy. Lud, 94, 264-283.

Mroczkowska, J. (2018). Kirgiskie małżeństwa przez porwanie. In: K. Baraniecka-Olszewska, I. Kabzińska, O. Tangad (eds.), Lokalne i globalne perspektywy azjanistyczne (pp. 271-294). Warszawa: Instytut Archeologii i Etnologii PAN. 
Pietrowiak, S. (2014). Usiądź albo będziesz nieszczęśliwa... Perswazja, normy i nacisk społeczny, czyli o praktykach matrymonialnych w północno-zachodnim Kirgistanie. Normy, Dewiacje i Kontrola Społeczna, 15, 289-309.

Portisch, A. (2009). Forty houses should forbid the girls: Bride-kidnapping amongst the Kazakh of western Mongolia. Newsletter of the International Institute for Asian Studies (IIAS), 51, 4-5.

Pritchard, M. (2009). Legends Borne by Life: Myth, Grieving and the Circulation of Knowledge within Kyrgyz contexts. MSc. Dissertation, The Ohio State University.

Sörnmo, G. (2013). Identity as a strategic resource: a study on alternative gender NGOs in Kyrgyzstan. Department of Human Geography.

Szynkiewicz, S. (1987). Płatności małżeńskie. In: Z. Staszczak (ed.), Słowniczek etnologiczny: terminy ogólne (pp. 275-277). Warszawa, Poznań: Państwowe Wydawnictwo Naukowe.

Ûdahin, K.K. (1965a). Kirgizsko-Russkij slovar'. Vol. 1: A-K. Maskva: Sovetskaya Entsiklopediya.

Ûdahin, K.K. (1965b). Kirgizsko-Russkij slovar'. Vol. 2: L-Z. Maskva: Sovetskaya Entsiklopediya.

Werner, C. (2009). Bride abduction in post-Soviet Central Asia: marking a shift towards patriarchy through local discourses of shame and tradition. Journal of the Royal Anthropological Institute, 15, 314-331.

Werner, C., Edling, Ch., Becker, C.M., Kim, E., Kleinbach, R., Esengeldievna Sartbay, F., Teachout, W. (2018). Bride kidnapping in post-Soviet Eurasia: a roundtable discussion. Central Asian Survey, 37/4, 582-610.

Wierzbicki, A., Załęski, P. (2008). Trybalizm a władza w Azji centralnej. Przykład Republiki Kirgiskiej. Pułtusk: Akademia Humanistyczna imienia Aleksandra Gieysztora.

Witort, B. (1994). Na weselu u Kazachów. In: A. Kuczyński (ed.), Polskie opisanie świata: studia z dziejów poznania kultur ludowych i plemiennych. Vol. 1, Azja i Afryka (pp. 155-159). Wrocław: Wydawnictwo Uniwersytetu Wrocławskiego.

Films

Butts, A. (2009). Kidnapped Brides, Al Jazeera: Witness (via YouTube). Part 1: https://www. youtube.com/watch?v=EjkWvt-OZLk\&list=PLhpE1CJOmGWaEonPvylIzLYxdzvTlKjmK (accessed: 25.03.2021). Part 2: https://www.youtube.com/watch?v=bU-Q-7jEAds (accessed: 25.03.2021)

Lom, P. (2004). Bride Kidnapping in Kyrgystan. Brooklyn, New York.

Online sources

Abdulaeva, Sh., Arjomand, V., Tursunov, N. (2005). Why women stay, http://faculty.philau. edu/kleinbachr/why_women_stay.htm (accessed: 6.07.2012).

Human Rights Watch (2018). Kyrgyz Republic 2018 Human Rights Watch Report. Country Reports on Human Rights Practices for 2018, United Stated Department of State, Bureau of Democracy, Human Rights and Labor. https://www.justice.gov/eoir/page/ file/1145036/download (accessed: 10.07.2020). 


\section{SUMMARY}

Bride kidnapping in Northern Kyrgyzstan as the initial stage of subjectivityforming process

Kyz ala kachuи (Kyrgyz: кыз ала качуy) translated as "to take a young woman and run away" is a form of women kidnapping for marriage purposes in Kyrgyzstan (Kyrgyz Republic). This term applies to either of the performed actions: kidnapping with permission from the future wife, and without her consent. In this article, I propose an anthropological interpretation of bride kidnapping, using the concept of 'person-making'. In my analysis, I go beyond the act of kidnapping itself, which I present as part of a wider social process. Drawing on my fieldwork in Northern Kyrgyzstan, I show that marriage through kidnapping is the first stage in the social process of building female subjectivity and the way of reproduction of Kyrgyz families. The reproduction takes place through the acquisition, familiarization, and constitution of subjectivity resulting from the collective agency of all the family members.

Keywords: Kyz ala kachuu, bride kidnapping, family, social roles, Kyrgyz Republic, post-Soviet states 